\title{
Múltiplos caminhos na pesquisa em comunicação
}

Temos o prazer de apresentar o primeiro número de 2013 da

Revista E-Compós. Tradicionalmente, dedicamos a primeira edição a temas livres, de modo a abrir espaço para a ampla variedade de perspectivas e temáticas que caracteriza o campo acadêmico da comunicação. Neste número, tivemos novamente um grande número de submissões qualificadas, que exigiram um esforço redobrado de nosso corpo de pareceristas, a quem de público agradecemos. Graças a este trabalho contínuo de qualificação, temos conseguido manter a regularidade de nosso periódico. A par da crescente procura dos/as pesquisadores pela E-Compós, publicamos neste número uma quantidade de textos superior à das edições anteriores, de modo a publicizar ao máximo a produção da área.

De modo convergente com esta posição de interface característica dos estudos de comunicação, esta edição inicia com 0 artigo de Luiz Claudio Martino e Katrine Tokarski Boaventura, O Mito da Interdisciplinaridade: história e institucionalização de uma ideologia, no qual a epistemologia de uma ciência inter, multi, trans ou mesmo indisciplinar é discutida.

No artigo Meio, Mediação, Agência: a descoberta dos objetos em Walter Benjamin e Bruno Latour, Erick Felinto explora 
convergências teóricas entre o pensamento de Bruno Latour e escritos da juventude de Walter Benjamin, matizando um debate sobre dois teóricos de grande relevância para a reflexão da área de comunicação.

No artigo John Hobson e a psicologia do jingoísmo - a metáfora da agulha hipodérmica e as origens da teoria crítica da propaganda, Francisco Rüdiger analisa um trabalho pioneiro dos estudos críticos da mídia, escrito em 1901, no qual são antecipados alguns dos principais elementos desta teoria, incluindo a célebre metáfora da seringa hipodérmica.

0 jornalismo é 0 assunto dos dois artigos seguintes. Em Construção de frame da mídia e cultura: os cultivos transgênicos em dois jornais brasileiros no 'ano da controvérsia', Luisa Massarani, Dominique Brossard, Carla Almeida, Bruno Buys e Emily Acosta Lewis analisam 0 intenso debate ocorrido no campo jornalístico brasileiro em 2003, acerca da introdução do cultivo de transgênicos em nosso país.

0 estudo do universo do jornalismo do ponto de vista de seus/suas trabalhadores/as é o tema do artigo Atividade de comunicação e trabalho dos jornalistas, de Roseli Figaro, no qual são apresentados dados de uma pesquisa com dezenas de profissionais de imprensa no estado de São Paulo.

0 artigo de César Geraldo Guimarães, Cristiane da Silveira Lima e Victor Ribeiro Guimarães, Mise-en-scène e experiência estética: o trabalho do espectador em 'A falta que me faz' busca explorar a interface entre espaço fílmico e experiência do/a espectador a partir da análise de um filme documentário.

Em Toda música (séria) é alemãe Prelúdio de uma geopolítica da música, Paulo Roberto Masella Lopes analisa 
a relação entre estética e nacionalismo alemão na teoria da música de Adorno e Nietzsche.

Em Tirando as máscaras: o reality show e a busca pela autenticidade no mundo contemporâneo, Bruno Campanella explora os sentidos atribuídos por participantes de uma comunidade de fãs do reality show Big Brother Brasil em termos do valor moral atribuído a uma suposta "autenticidade" dos/as participantes do confinamento midiático.

0 artigo de Alexandre Barbalho e Alicianne Gonçalves de Moraes, Questão racial e esfera pública virtual: uma análise do site da Secretaria de Políticas de Promoção da Igualdade Racial avalia a ação do site deste órgão do governo federal em termos da promoção de uma interface digital entre estado e sociedade. Abre espaço nessa edição para a primeira das duas resenhas aqui publicadas, de autoria de Ceiça Ferreira, sobre o livro "Aqui ninguém é branco", de Liv Sovik. Com o título A invisibilidade da branquitude na mídia e na música brasileira, Ferreira aborda uma temática que ainda merece maior destaque nas pesquisas em comunicação. Em seguida, explorando o já sedimentado campo dos estudos de cinema, Thais Continentino Blank e Patricia Furtado Machado criticam 0 livro de Sylvie Lindeperg "Nuit et brouillard, un film dans l'histoire", sobre o filme "Noite e neblina", de Alain Resnais. Finalizando a edição, o artigo de Priscila Martins Dionízio, Entre mundos: um encontro com o outro na tessitura da narrativa jornalística analisa a dimensão da alteridade no jornalismo a partir do programa Nova Africa, exibido na TV Brasil. 0 artigo foi elaborado a partir da Dissertação de Mestrado vencedora do Prêmio Compós de Dissertações 2012, o que reforça a relevância da temática do jornalismo no grande escopo temático da comunicação. 
Os campos de conhecimento abordados pelos artigos

e resenhas desta edição confirmam a pluralidade de

temáticas, metodologias e teorias que formam a área de

Comunicação, extraindo dessa rica diversidade a força da

área e de nossa revista.

Desejamos uma ótima leitura!

Adriana Braga e Felipe Trotta

Comissão Editorial 